Tür Turizm Araştırmaları Dergisi
2021, 5(2): $1299-1318$.
DOI: $10.26677 / \mathrm{TR} 1010.2021 .767$

\title{
Kültürel Miras Farkındalığı: Kastamonu Üniversitesi Turizm Fakültesi Öğrencileri Üzerine Bir Araştırma
}

Arş. Gör. Dr. Emrah YAŞARSOY, Kastamonu Üniversitesi, Turizm Fakültesi, Kastamonu, eposta: eyasarsoy@kastamonu.edu.tr

ORCID: https://orcid.org/0000-0002-9541-6601

Arş. Gör. Dilara Eylül KOÇ, Kastamonu Üniversitesi, Turizm Fakültesi, Kastamonu, e-posta: dkoc@kastamonu.edu.tr

ORCID: https://orcid.org/0000-0003-3990-7366

Doç. Dr. Şevki ULEMA, Sakarya Uygulamalı Bilimler Üniversitesi, Turizm Fakültesi, Sakarya, eposta: ulema@subu.edu.tr

ORCID: https://orcid.org/0000-0002-5874-8797

Öz

Bu araştırma, Kastamonu Üniversitesi Turizm Fakültesi'nde öğrenim gören öğrencilerin Kastamonu'nun sahip olduğu kültürel miras farkındalığını belirlemek ve bu farkındalığı artırmak amacıyla yapılmıştır. Araştırma birbiri ile ilişkili iki sorunu çözmek için tasarlanmıştır. Öncelikle, öğrencilerin mevcut farkındalık düzeyleri ölçülmeye çalışılmıştır. Sonrasında ise öğrencilerin farkındalık düzeylerinin düşük olduğu noktaların nasıl artırılabileceği araştırmanın kapsamını oluşturmuştur. Nicel olarak tasarlanan bu araştırmada, anket tekniği kullanılmıştır. Anket formları, kolayda ve gönüllülük yaklaşımlarıyla belirlenmiş 230 katılımcıya elektronik ortamda uygulanmıştır. Araştırmadan elde edilen veriler, SPSS 22.0 ve MAXQDA programlarıyla analiz edilmiştir. Araştırma sonucunda, katılımcıların kültürel miras farkındalıklarının genel anlamda yüksek olduğu belirlenmiştir. Özellikle, "Atatürk ve Şerife Bacı Anıtı”, "Kastamonu Kalesi” ve "Saat Kulesi" nin en fazla bilinen yerler arasında yer aldığı saptanmıştır. Yapılan karşılaştırma testlerinde, kültürel miras farkındalığının katılımcıların cinsiyetlerine ve bölümlerine göre bir farklılık göstermediği, ancak yaş grupları arasında anlamlı farklılıkların bulunduğu belirlenmiştir. Katılımcılar, Kastamonu turizminin gelişimi için tanıtım faaliyetlerinin etkili bir şekilde yapılması gerektiğini, festival tarzı çeşitli etkinliklerin arttırılmasının son derece önemli olduğunu, alt yapı ve üst yapı çalışmalarının hızlandırılması gerektiğini ve yeni yatırımların yapılmasının elzem olduğunu vurgulamışlardır.

Anahtar Kelimeler: Kültürel Miras, Farkındalık, Turistik Ürün, Kastamonu.

Makale Gönderme Tarihi: 26.03.2021

Makale Kabul Tarihi: 05.06.2021

\section{Önerilen Atıf:}

Yaşarsoy, E., Koç, D. E. ve Ulema, Ş. (2021). Kültürel Miras Farkındalığı: Kastamonu Üniversitesi Turizm Fakültesi Öğrencileri Üzerine Bir Araştırma, Türk Turizm Araştırmaları Dergisi, 5(2): 1299-1318.

(C) 2021 Türk Turizm Araştırmaları Dergisi. 


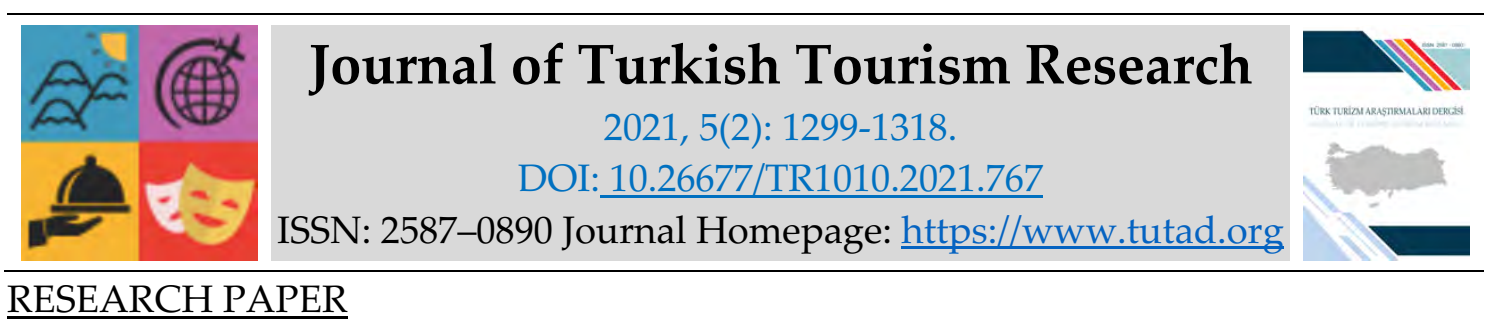

\title{
Cultural Heritage Awareness: A Research on Kastamonu University Faculty of Tourism Students
}

Dr. Emrah YAŞARSOY, Kastamonu University, Faculty of Tourism, Kastamonu, e-mail: eyasarsoy@kastamonu.edu.tr ORCID: https://orcid.org/0000-0002-9541-6601

Research Assistant Dilara Eylül KOÇ, Kastamonu University, Faculty of Tourism, Kastamonu, email: dkoc@kastamonu.edu.tr ORCID: https://orcid.org/0000-0003-3990-7366

Associate Prof. Dr. Şevki ULEMA, Sakarya University of Applied Sciences, Faculty of Tourism, Sakarya, e-mail: ulema@subu.edu.tr

ORCID: https://orcid.org/0000-0002-5874-8797

\begin{abstract}
This research was carried out in order to determine the cultural heritage awareness of Kastamonu students and to increase this awareness. The research is designed to solve two interrelated problems. First of all, the current awareness levels of the students were tried to be measured. Then, how to increase the points where the students' level of awareness could be increased constituted the scope of the research. The questionnaire technique was used in this quantitatively designed research. The questionnaire forms were implemented electronically to 230 participants who were determined with convenience sampling method and voluntary approach. The data obtained from the research were analyzed with SPSS 22.0 and MAXQDA. As a result of the research, it was determined that the cultural heritage awareness of the participants was generally high. In particular, it was specified that the "Atatürk and Şerife Bacı Monument", "Kastamonu Castle" and "Clock Tower" are among the most well-known places. As a result of the comparison tests applied, it was determined that cultural heritage awareness did not differ according to the genders and departments of the participants, but significant differences were found between age groups. The participants emphasized that promotion activities should be carried out effectively for the development of tourism in Kastamonu, it is extremely important to increase various festival-style activities, the infrastructure and superstructure works should be accelerated and it is essential to make new investments.
\end{abstract}

Keywords: Cultural Heritage, Awareness, Tourist Product, Kastamonu

Received: 26.03.2021

Accepted: 05.06.2021

\section{Suggested Citation:}

Yaşarsoy, E., Koç, D. E. and Ulema, Ş. (2021). Cultural Heritage Awareness: The Case of Kastamonu University Faculty of Tourism, Journal of Turkish Tourism Research, 5(2): 1299-1318.

(C) 2021 Türk Turizm Araştırmaları Dergisi. 


\section{Gíriş}

Özellikle belli bir toplumun belirli bir zamandaki gelenek ve inançları, sanatları, yaşayış biçimleri olarak tanımlanan kültür (Cambridge, 2020; Oxford, 2020); Türk Dil Kurumu'nda daha detaylı olarak açıklanmıştır. TDK sözlüğünde (2020) kültür; "tarihsel, toplumsal gelişme süreci içinde yaratılan bütün maddi ve manevi değerler ile bunları yaratmada, sonraki nesillere iletmede kullanılan, insanın doğal ve toplumsal çevresine egemenliğinin ölçüsünü gösteren araçların bütünü" olarak tanımlanmıştır. Mancı (2019)'nın tanımına göre kültür, bir toplumun ya da toplumların birikimli uygarlığıdır. Bir başka ifadeyle kültür, toplumun bir üyesi olarak insan tarafından kazanılan inançları, bilgileri, sanatı, hukuku, ahlakı, gelenekleri, belirli yetenekleri ve alışkanlıkları içeren öğrenilmiş davranışların toplamıdır (Bahtiyar Karadeniz, 2020: 41). Srivastava (2015: 338)'ya göre kültür, hayatımızın tüm iç ve dış faaliyetlerini içermektedir, yani bir insanın doğum öncesinden doğum sonrasına kadar hiç bitmeyen, devamlılığı olan bir süreç olarak yolculuğudur. Kısacası kültür, yaşam felsefesi olmakla beraber bir yaşam tarzıdır.

Miras ise; genellikle geçmişten geleceğe aktarılan "geçmişin çağdaş kullanımı" şeklinde tanımlanmaktadır (Emekli, 2012: 1). Doğaner (2003: 1) miras1; "tarih, sanat, etnoloji, sosyoloji, antropoloji ve dil alanlarında sahip olunan üstün değerli mekân, varlık ve olaylar bütünü" olarak ifade ederken, Uluslararası Kültürel Turizm Tüzüğü (1999)'nde ise miras, “doğal ve kültürel çevreyi içine alan geniş bir kavram olduğu ve çağdaş yaşamın bütünleyici bir parçası" olarak tanımlanmıştır. Kültür ve miras tanımlarından yola çıkarak; kültürel miras için de kültürel değerlerin (Shimray ve Ramaiah, 2017), geleneksel bilgilerin (Vecco, 2010: 321), festivallerin, ritüellerin, inanç sistemlerinin, kıyafetlerin, sanatların vb. sözlü ve sözsüz formlarda gelecek nesillere aktarılması olarak tanımlanabilir (Jokilehto, 2005; Shimray ve Ramaiah, 2019: 1).

Nesilden nesile aktarılan kültürel miras unsurları, tarihsel süreç içinde toplum kültürünün bir çıktısıdır. Bu nedenle kültürel miras unsurları toplumların kaynakları olarak karşımıza çıkmaktadır. Bu anlamda kültürü yansıtan eserlere, ortaya çıkış tarihlerini gelecek nesillere gösteren tanıklar denilmektedir. Topluma ait kültürel mirasın korunması aynı zamanda insanlık tarihinin de bir şekilde korunması demektir (Köroğlu, Ulusoy-Yıldırım ve Avcıkurt, 2017: 99). Ayrıca kültürel miras unsurları yeri doldurulamayan bir hazineyi oluşturmaktadır. Kültürel mirasın geçmişle gelecek arasında köprü kurma özelliği nedeniyle de yönetimlerine dikkat edilmesi gerekmektedir (Tören, Kozak ve Demiral, 2012: 70).

Turizm açısından ele alındığında miras, her zaman turistlerin ilgisini çeken önemli bir kaynak olmasına rağmen, kültürel miras son yıllarda üzerinde durulan bir konu haline gelmiştir. Miras, tarihsel unsurlar ile doğal değeri, peyzajı, sanatı ve kültürü de içine alan bir bütündür. Bu bütünlükten yararlanan turizm sektörünün temelini oluşturan mirası doğal ve kültürel olarak ikiye ayırmak mümkündür (Doğaner, 2003: 5; Emekli, 2012: 1). Bu her iki miras da insanlara aittir ve onların evrensel değerlerini anlamak, takdir etmek ve korumak herkesin hak ve sorumluluğundadır (ICOMOS, 1999).

Ev sahibi ülkenin kültürünü farklı kültürlerden turistlere gösterme ve tanıtma fırsatı genellikle toplum için bir gurur kaynağıdır. Bu ifade turizmin toplum ve kültür üzerindeki olumlu etkisi bağlamında değerlendirilmektedir (Avcıkurt, 2017). Ev sahibi topluluk, kültürünü farklı kültürel geçmişlere sahip turistlere gösterme ve tanıtma fırsatına sahiptir. Bu koşullar altında, turizm ve kültürel miras arasındaki karşılıklı bağımlılık giderek daha açık hale gelmiştir. Kültürel miras, turizmin gelişmesinin temelini oluşturmaktadır (Endresen, 1999). Bu nedenle kültürel miras farkındalığ 1 da herhangi bir kültürel mirasın geliştirilmesi ve korunmasında hayati bir unsur olarak görülmelidir (Shimray ve Ramaiah, 2019: 1; Shankar ve Swamy, 2013: 695). 
Anlatılanlar ışığında, turizm sektöründe yer alarak birer kültür elçisi olabilmek için eğitim alan öğrencilerin, turizmin temel taşlarından olan kültürel miras hakkındaki farkındalıkları önem kazanmaktadır. Bu çalışmanın amacı, turizm eğitimi alan öğrencilerin kültürel miras farkındalıklarının ortaya çıkarılmasıdır. Turizm eğitimi alan öğrencilerin ileride birer turizm profesyoneli olacağı varsayıldığından, bu bireylerin kültürel miras farkındalıklarının artmasının Kastamonu turizmine turizm gelirleri, turist sayısı ve hizmet kalitesi açısından katkı sağlayacağ düşünülmektedir. Literatürde konu ile ilgili çalışmalar yapılmış olmasına rağmen, birçok kültürel değerlere sahip Kastamonu ilinde turizm eğitimi alan öğrencilerin kültürel miras farkındalığına ilişkin çalışmanın eksikliği nedeniyle literatüre katkı sağlayacağ öngörülmektedir.

\section{KAVRAMSAL ÇERÇEVE}

İnsanların etnik kökenlerini, geçmişlerini, farklı yaşam tarzlarını yansıtan kültürel miras kaynakları; arkeolojik, etnografik, tarihi eserler ve mimari öğeleri kapsamaktadır (Köroğlu vd., 2018: 99). Son yıllarda insanlar kökenlerine, geçmişlerine ve farklı yaşam biçimlerine ilgi duymaya başlamış, bu nedenle kültürel değerler turizmin odak noktası haline gelmiştir (Emekli, 2012: 1). Ayrıca kültürel miras değerleri, insanın gelişimi, kültürel çeşitliliğin ve kültürlerarası iletişimin artırılması için bir kaynak (Council of Europe, 2005: 2) ve kaynakların sürdürülebilir kullanım ilkesine dayalı ekonomik gelişme modelinin bir parçası ile (ISSMEP, 2014:16) bir toplumun refahının en değerli parçası (Kurtar ve Somuncu, 2013: 36) olarak görülmektedir.

Kültürel miras, Kültür ve Turizm Bakanlığı (2009: 3)'ın tanımıyla “geçmişten miras alınan ve değişik gerekçelerle geleceğe miras bırakılmak istenen, fiziksel olarak varlığı olan ve insanlar tarafından yapılmış her türlü eserler ile bir topluma ait değerler bütünüdür." Diğer bir tanıma göre kültürel miras, "bir toplumun geçmişi ile ilgili, onu kimliklendiren, yaşamsal süreklilikle birlikte günümüze ulaşan yerel ve evrensel değer niteliği taşıyan her türlü somut ve somut olmayan varlıklardır" (İSMEP, 2014: 12). Bu tanımlardan hareketle, genel olarak kültürel miras “bir kültüre ait olan değerler bütünü"dür (Akpirinç ve Manc1, 2019: 246).

Kültürel mirasın 17 Ekim 2003 tarihinde Paris'te imzalanan UNESCO Somut Olmayan Kültürel Mirasın Korunması Sözleşmesi'nde somut ve somut olmayan kültürel miras şeklinde sinıflandırıldığ1 görülmektedir (UNESCO, 2003: 2). Buna bağlı olarak da kültürel miras tanımlamalarında, somut ve soyut unsurların tümü olarak ifade edilmektedir. Örneğin, İstanbul Valiliği tarafından kültürel mirasın korunması adı altında yayınlanan rehber kitaplarında (İSMEP, 2014), kültürel miras insan hafızasını oluşturan tüm somut ve soyut değerler olarak ifade edilmiştir.

Dünya, kültürel ve doğal mirasın korunmasına ilişkin UNESCO Sözleşmesinde (1972), “kültürel miras" ifadesi tarih, sanat ve bilim açısından istisnai evrensel değere sahip anıtları, yapı toplulukları ve sit alanların kapsamaktadır. Anıtlar; mimari eserler, heykel ve resim alanındaki şaheserler, arkeolojik nitelikte yapılar, kitabeler ve mağaralar, yapı toplulukları; mimarileri, uyumları ve arazi üzerindeki yerleri nedeniyle tarih, sanat ve bilim açısından istisnai değere sahip ayrı ya da birleşik yapı toplulukları, sit alanları; tarihsel, estetik, etnolojik veya antropolojik bakımlardan istisnaî evrensel değeri olan insan ürünü eserler veya doğa ve insanın ortak eserleri ve arkeolojik sitleri kapsayan alanlar olarak belirtilmektedir. Skounti (2011: 29) UNESCO Sözleşmesi (1972) tarafından tanımlandığı şekliyle dünya mirası, geçmişin büyük tanıklıklarının uzun bir koruma hareketi olduğunu ve bu hareketin Avrupa Rönesans1, Atina Tüzüğü (Charter of Athens, 1931), Lahey Sözleşmesi (The Hague Convention, 1954-Vecco, 2010: 322) ve Venedik Tüzüğü (Charter of Venice, 1964) ile paralel bir hareketten kaynaklandığını ifade etmektedir. 
Ayrıca UNESCO Sözleşmesi (1972)'nde kültürel mirasın kökeninin, “M.Ö. 2. yüzyılın ortalarında geliştirilen Dünyanın Yedi Harikası Listesi"nde bile görüldüğü belirtilmektedir.

Kültürel miras varlıklarının korunması ve sürdürülebilirliğinin sağlanması için bu konuda farkındalığın belirlenmesi en önemli yollardan biridir. Geçmişten günümüze kültürel mirasın, yaratıcılığın kaynağı ve keşif için itici güç, genç bireylere gelişim firsatı sunan, bireylere güzel deneyimler yaşatan, dünyaya ve hayata bakışımıza anlam katan değerler (İSMEP, 2014: 8-11-15) olduğu varsayılırsa, özellikle genç bireylerde kültürel miras farkındalığının yaratılması oldukça önemli bir konu olmaktadır. Örneğin, Shankar ve Swamy (2013: 698) yapmış oldukları çalışmada, Mysore'un sahip olduğu kültürel mirası hakkında küçük bir kitapçık yayınlandığını, ayrıca turistler, yetkililer, halk ve çeşitli eğitim düzeyine sahip öğrenciler için atölye çalışmaları, seminerler, kültürel miras kapsamında değerlendirilen yapıların fotoğraf sergileri ve miras alanlarına ziyaretler düzenlendiğini belirtmişlerdir. Kültürel miras komisyonu tarafından özellikle tur rehberleri için kültürel miras farkındalık programları ve çeşitli devlet dairesi yetkilileri için miras yapılarının korunması ve bakımı konusunda eğitim programı düzenlendiğini ve bunlara ek olarak, üniversite öğrencileri arasında farkındalık yaratmak için üniversitelerde 2007 yılında miras kulüpleri açıldığını ifade etmişlerdir.

İlgili literatür incelendiğinde de kültürel miras farkındalığı konusunda çeşitli eğitim düzeylerindeki öğrencilere yönelik yapılan çalışmalar olduğu görülmektedir. Örneğin, ilköğretim düzeyinde (Gümüş ve Özüpekçe, 2009; Jaafar, Noor ve Rasoolimanesh, 2014; Uçar, 2014; Aşık, Özel ve Korzay, 2016; Gürel ve Çetin, 2019; Şekerci ve Doğan, 2020), orta öğretim düzeyinde (Gümüş ve Adanalı, 2011; Barghi, Zakaria, Jaafar ve Hamzah, 2016) ve üniversite düzeyinde (Keçe ve Dinç, 2010; Metin, 2010; Keçe, 2015; Dinç, Erdil ve Keçe, 2011; Çetin ve Akkaya, 2013; Selanik Ay ve Kurtdede Fidan, 2013; Çetin ve Gürgil, 2014; Ablak, Dikmenli ve Çetin, 2014; Akkuş, Karaca ve Polat, 2015; Ahmed, 2017; Karaca- Yılmaz, Şahbudak, Akkuş ve Işkın, 2017; Güneş ve Alagöz, 2018; Köroğlu, Ulusoy Yıldırım ve Avcıkurt, 2018; BahtiyarKaradeniz, Sarı ve Kabacık, 2018; Mancı, 2019 ve Bahtiyar-Karadeniz, 2020) kültürel miras farkındalığına dair araştırmalar gerçekleştirilmiştir.

Bahtiyar-Karadeniz (2020) ve Bahtiyar-Karadeniz, Sarı ve Kabacık (2018) Ordu Üniversitesi öğrencilerinin kültürel miras bilincini araştırmış ve orta düzeyde bir farkındalık belirlemiştir. Güneş ve Alagöz (2018), Erzincan Üniversitesi öğrencilerin kültürel miras tutumlarına yönelik yaptıkları çalışmada, öğrencilerin kültürel miras değerlerine ilgili oldukları ve bu değerleri korumaya istekli oldukları sonucu ortaya çıkmıştır. Akkuş vd., (2015) ile Karaca-Yılmaz vd., (2017) Cumhuriyet Üniversitesi öğrencilerinin kültürel miras farkındalığını incelemiş ve inceleme sonucunda öğrencilerin Sivas kültürel mirasına ilişkin farkındalıklarının düşük olduğu görülmüştür. Buluk (2017) tarafından Çanakkale Onsekiz Mart Üniversitesi öğrencilerinin kültürel miras farkındalıklarını tespit etmek amacıyla yapılan çalışmada, öğrencilerin kültürel miras farkındalıklarının genel olarak düşük olduğu sonucuna ulaşılmıştır. Ahmed (2017) Suudi Arabistan'da yer alan Hail Üniversitesi öğrencilerinin ulusal miras farkındalı̆̆ının değerlendirilmesi üzerine yaptığı çalışma sonucunda öğrencilerin ulusal miras unsurlarına yönelik farkındalıklarının üniversite öncesi dönemden başlaması gerektiği sonucuna ulaşmıştır. Keçe (2015)'nin Gazi Üniversitesi öğrencilerinin Ankara'nın tarihi ve kültürel değerlerine yönelik farkındalıkları üzerine yaptığı çalışmada, öğrencilerin tarihi ve kültürel değerlere ilişkin bilgilerinin yeterli düzeyde olmadığını ortaya çıkarmıştır. Ablak vd., (2014), Ahi Evran Üniversitesi öğrencilerinin kültürel değerler farkındalıkları üzerine yaptıkları çalışmada Kırşehir'in sahip olduğu tarihi ve kültürel miras unsurlarına ilişkin farkındalık sahibi oldukları sonucuna ulaşmıştır. Aktın, Karakuş ve Sağlam (2013), Sinop'un kültürel değerlerine yönelik Sinop Üniversitesi öğrencilerinin farkındalık seviyelerini ölçen çalışmasında öğrencilerin Sinop'taki tarihi ve kültürel eserler hakkında farkındalık noktasında yeterli olmadıkları 
sonucuna ulaşılmıştır. Metin (2012), Çankırı Karatekin Üniversitesi öğrencileriyle tarihi ve kültürel eserler hakkındaki farkındalıklarını incelemiş ve öğrencilerin Çankırı'ya ait tarihi ve kültürel miras eserlerine ilgili oldukları ancak aynı öğrencilerin Çankırı ve yakın çevresindeki kültürel değerler hakkında genel bilgi sahibi olmadığı sonucu elde edilmiştir. Dinç, Erdil ve Keçe (2011) tarafından Uşak Üniversitesi öğrencileriyle tarihi ve kültürel unsurlar üzerine farkındalık düzeylerinin belirlenmesine yönelik yapılan çalışmada, Uşak'ın sahip olduğu tarihi ve kültürel değerlere öğrencilerin farkındalıklarının yeterli düzeyde olmadığı sonucu ortaya çıkmıştır.

Çalışmalarda öğrencilerde kültürel miras farkındalığı yaratılarak, sahip olunan kültürel miras değerlerinin nesilden nesile korunarak aktarılacağı vurgulanmıştır. Ayrıca Jaafar vd., (2014: 31) ise çalışmalarında, gençler arasında dünya mirasına ilişkin farkındalığın gelişmesi için, gençlerin bu alanla ilgili faaliyetlere etkin katılımının bir ön koşul olduğunu belirtmişlerdir.

Literatürde ilgili çalışmaları toparlamak gerekirse, kültürel miras farkındalığı ile ilgili farklı zamanlarda çeşitli araştırmaların yapıldığı saptanmıştır. Genel anlamda bu araştırmaların öğrencilere yönelik gerçekleştirildiği görülmektedir. Bu durumun böyle olmasında, kültürel miras farkındalı̆̆ının genelde turizm eğitiminde önemli bir yer tutması gösterilebilir. Çalışmalara konu olan kültürel unsurların gelecek nesillere aktarılabilmesi için tarihi yerlerin korunması ve geliştirilmesi ile bu değerlerin turizm faaliyetleri kapsamında kullanılmasının sağlanması için kültürel değerlere gerekli özen gösterilmelidir. Hiç şüphe yok ki, bu özenin sağlanmasının temel koşullarından biri, tarihi ve kültürel değerlere ilişkin verilen eğitimdir. Böylece bireyler arasında tarihi ve kültürel değerlere yönelik farkındalık gelişecek ve artacak, bireyler değerleri koruyabilecek ve geleceğe aktarabilecek, aktarılan bu değerlerden ise turizm sektöründe yararlanılarak ülke ekonomisine katkı sağlayacaktır. Dolayısıyla bu değerlerin yaşatılması, varlığının sürdürülmesi ve gelecek nesillere aktarılması açısından bireyin tarihi ve kültürel mirasına yönelik tutumları çok önemlidir (Meydan-Uygur ve Baykan, 2007: 46; Ablak vd., 2014: 174; Güdü-Demirbulat, Saatçi ve Avcıkurt, 2015: 62; Karaca-Yılmaz vd., 2017). Yukarıda anlatılanların ışığında, çalışmada aşağıdaki hipotezler oluşturulmuştur.

H1: Kültürel miras farkındalığı cinsiyete göre farklılık göstermektedir.

H2: Kültürel miras farkındalığı yaşa göre farklılık göstermektedir.

H3: Kültürel miras farkındalığı bölüme göre farklılık göstermektedir.

\section{YÖNTEM}

Bu araştırma, Kastamonu Üniversitesi Turizm Fakültesi'nde öğrenim gören öğrencilerin yöreyle ilgili kültürel miras farkındalığını ölçmek ve bu farkındalığı artırmak amacıyla gerçekleştirilmiştir. Araştırma, öğrencilerin yörenin kültürel mirası hakkında bilgi sahibi olmaları ve bu bilgiyi yörenin turizminin gelişimi bakımından uygulamada kullanmaları açısından önem taşımaktadır. Araştırma birbiri ile ilişkili iki sorunu çözmek için tasarlanmıştır. Öncelikle, öğrencilerin mevcut farkındalık düzeyleri ölçülmeye çalışılmıştır, sonrasında ise öğrencilerin farkındalık düzeylerinin düşük olduğu noktaların nasıl artırılabileceği araştırmanın kapsamını oluşturmaktadır.

Araştırmanın kapsam ve amacına ve bunlara koşut belirlenmiş olan araştırma sorularına geçerli ve güvenilir cevaplar sağlayacak yöntem "Tarama" dır. Bu sebeple araştırmada "Tarama Modeli" işe koşulmuştur. Tarama Modelleri geçmişte ya da halen var olan bir durumu olduğu gibi betimlemeyi amaçlayan araştırma yaklaşımlarıdır. Modelde araştırmaya konu olay, birey ya da nesne kendi koşulları içinde olduğu gibi tanımlanmaya çalışılır. Onları herhangi bir şekilde 
değiştirme ve/ya etkileme çabası gösterilmez. Başka bir deyişle, var olan durum olduğu gibi ortaya konur (Karasar, 1984). Tarama Modeli'nde bilimin gözleme, kaydetme, olaylar arasındaki ilişkileri saptama, kontrol edilen değişmez ilişkiler üzerinde genellemelere varma amaçları vardır. Bir başka ifadeyle, bilimin tasvir işlevi ön plandadır (Yıldırım ve Şimşek, 2008).

Anlatılanlar ışığında, araştırmada işe koşulan modelin bir "İlişkisel Tarama Modeli" olduğunu söylemek mümkündür. Bu modelle araştırma sorularına geçerli ve güvenilir çözümler bulabilmek amacıyla öncelikle ilgili yazın derinlemesine taranmış ve Mancı (2019) tarafından yapılan "Üniversite Öğrencilerinin Kültürel Miras Farkındalığı ve Deneyimleri: Harran Üniversitesi Örneği - Şanlıurfa" başlıklı çalışmadan ve Yaşarsoy ve Oktay (2020)'ın "Yerli Turistlerin Şanlıurfa Turizmi ile İlgili Algılarını Belirlemeye Yönelik Bir Araştırma" başlıklı çalışmasından yararlanılarak bir anket formu geliştirilmiştir. Kültürel miras farkındalığ ölçeğinde yer verilen turistik değerler belirlenirken, Kastamonu İl Kültür ve Turizm Müdürlüğü (2020) internet sayfasında yer alan kültürel miras öğelerinden faydalanılmıştır. Geliştirilen anket kolayda ve gönüllülük yaklaşımlarıyla belirlenmiş katılımcılara elektronik ortamda uygulanmiştır.

Kastamonu Üniversitesi Turizm Fakültesinde hâlihazırda lisans düzeyinde öğrenim gören 465 kişi araştırmada görüşüne başvurulan katılımcıların kaynağını oluşturmuştur. Bununla birlikte, araştırma örneklemi olarak gönüllülük esasına göre belirlenmiş 465 kişilik bir anakütleyi temsil ettiğine inanılan 230 kişinin görüşüne başvurulmuştur (Krejcie ve Morgan, 1970). Araştırma örnekleminde yalnızca 18 yaş ve üzeri yetişkin ve Türkçe konuşabilen bireylere yer verilmiştir. Araştırma verileri 13 Ağustos 2020 ve 16 Şubat 2021 tarihleri arasında toplanmıştır.

Araştırma sürecinde anket tekniği ile elde edilen veriler niteliklerine göre çözümlenmiştir. Katılımcların demografik bilgilerini elde etmeye yönelik hazırlanmış olan kategorik değişkenler sıklık ve yüzdelerle, kültürel miras farkındalığı, şehrin özellikleri ve şehrin sahip olduğu değerlere yönelik beşli Likert tipi ölçeğe göre hazırlanmış bağımsız değişkenlerin yer aldığı kısımlar ise bağımsız örneklem t-testi ve ANOVA testleri ile çözümlenmiştir. Bu analizler çerçevesinde ayrıca güvenirlik düzeyi için Cronbach's Alfa hesaplaması yapılmıştır. Tüm çözümlemeler (analizler) için Sosyal Bilimlerde yaygın olarak kullanılan SPSS'ten yararlanılmıştır. Ayrıca, araştırmada kullanılan 2 adet açık uçlu sorunun cevapları için ise MAXQDA programından faydalanılmış ve bu program üzerinden kod haritaları çıkarılmıştır.

\section{ARAŞTIRMANIN BULGULARI}

Araştırmanın bu kısmında, öncelikle katılımcıların demografik özelliklerine ve kültürel miras farkındalığına ait ifadelerin önem ortalamalarına yer verilmiştir. Ardından, Kastamonu'nun taşıdığı değerler ve sahip olduğu değerlere ilişkin frekans analizi ve kentin özelliğine ilişkin frekans analizi sonuçlarından söz edilmiştir. Son olarak, güvenirlik ve normallik testlerinin yanı sıra karşılaştırmalı testlerin sonuçları ve iki adet açık uçlu soruya verilen cevaplar araştırmanın bulgularını oluşturmuştur.

\section{Katılımcıların Demografik Özelliklerine İlişkin Frekans Analizi}

Tablo 1'e bakıldığında, katılımcıların \%61,7'sinin kadın olduğu ve \%90,4'ünün ise 18-24 yaş aralığında olduğu görülmektedir. Katılımcıların \%53,5'i turizm rehberliği bölümünde öğrenim görür iken, \%27'si turizm işletmeciliği bölümünde; \%19,5'i ise gastronomi ve mutfak sanatları bölümünde öğrenim görmektedir. Katılımcıların doğup büyüdükleri şehirler arasında $\% 4,8$ ile 
Ankara ile İstanbul ilk sırada yer almaktadır. Diğer seçeneğinde ise Türkiye'nin her bölgesinden ve Afganistan, Azerbaycan, Endonezya, Kazakistan, Kırgızistan, Suudi Arabistan ve Türkmenistan ülkelerinden katılımclların olduğu belirlenmiştir.

Tablo 1. Katılımcıların Demografik Özelliklerine İlişkin Frekans Analizi

\begin{tabular}{|c|c|c|c|c|c|c|c|}
\hline & & $\mathbf{n}$ & $\%$ & & & $\mathrm{n}$ & $\%$ \\
\hline \multirow[t]{3}{*}{ Cinsiyet } & Kadın & 142 & 61,7 & \multirow[t]{4}{*}{ Bölüm } & $\begin{array}{c}\text { Turizm } \\
\text { İşletmeciliği }\end{array}$ & 62 & 27,0 \\
\hline & Erkek & 88 & 38,3 & & $\begin{array}{l}\text { Turizm } \\
\text { Rehberliği }\end{array}$ & 123 & 53,5 \\
\hline & Toplam & 230 & 100,0 & & $\begin{array}{c}\text { Gastronomi } \\
\text { ve Mutfak } \\
\text { Sanatları }\end{array}$ & 45 & 19,5 \\
\hline \multirow[t]{8}{*}{ Yaş } & 18 yaş altı & - & - & & Toplam & 230 & 100,0 \\
\hline & $18-24$ & 208 & 90,4 & \multirow[t]{7}{*}{ Şehir } & Ankara & 11 & 4,8 \\
\hline & $25-31$ & 16 & 7,0 & & İstanbul & 11 & 4,8 \\
\hline & 32 ve üzeri & 6 & 2,6 & & Kastamonu & 8 & 3,5 \\
\hline & \multirow[t]{4}{*}{ Toplam } & \multirow[t]{4}{*}{230} & \multirow[t]{4}{*}{100,0} & & Zonguldak & 8 & 3,5 \\
\hline & & & & & İzmir & 8 & 3,5 \\
\hline & & & & & Diğer & 184 & 79,9 \\
\hline & & & & & Toplam & 230 & 100,0 \\
\hline
\end{tabular}

\section{Kültürel Miras Farkındalığına İlişkin Önem Ortalaması}

Kültürel miras farkındalığı ölçeğinin güvenirlik testi sonucu 0,937 çıkmıştır. Kültürel miras farkındalığına dair önem ortalaması analizinde, 5- Çok iyi biliyorum .... 1- Hiç bilmiyorum şeklinde oluşturulan likert tipi ölçeğe göre Tablo 2'de de görüldüğü şekilde Saat Kulesi $(4,40)$, Kastamonu Kalesi $(4,33)$ ve Atatürk ve Şerife Bacı Anıtı $(4,14)$ en çok bilinen yerler olarak ifade edilirken, Taşköprü Kent Tarihi Müzesi $(2,27)$, Pompeipolis Antik Kenti $(2,38)$ ve Taşköprü Kalekapı (Donalar) Kaya Mezarı $(2,40)$ en az bilinen yerler olarak belirtilmiştir.

Tablo 2. Kültürel Miras Farkındalığı Önem Ortalaması

\begin{tabular}{lcc}
\hline & Ortalama & ss \\
\hline Arkeoloji Müzesi & 3,67 & 1,23370 \\
\hline Atabey Gazi Camii (Kırk Direkli) & 3,08 & 1,39022 \\
\hline Atatürk ve Şerife Bacı Anıtı & 4,15 & 1,20945 \\
\hline Evkaya Mezarları & 2,57 & 1,38990 \\
\hline Hz. Pir Şeyh Şaban-1 Veli & 3,87 & 1,29171 \\
Külliyesi & & \\
\hline İnebolu Evleri ve Konakları & 2,93 & 1,41998 \\
\hline İsmailbey Külliyesi & 3,47 & 1,39766 \\
\hline Kastamonu Hükümet Konağı & 3,82 & 1,30556 \\
\hline Kastamonu Kalesi & 4,33 &, 95049 \\
\hline Kastamonu Kent Tarihi Müzesi & 3,41 & 1,42001
\end{tabular}




\begin{tabular}{lcc}
\hline $\begin{array}{l}\text { Kurtuluşa Giden Yolda İnebolu } \\
\text { Kent Müzesi }\end{array}$ & 2,58 & 1,36406 \\
\hline $\begin{array}{l}\text { Livapaşa Konağı - Etnografya } \\
\text { Müzesi }\end{array}$ & 3,55 & 1,46424 \\
\hline Mahmutbey Camii & 3,13 & 1,43771 \\
\hline $\begin{array}{l}\text { Mimar Vedat Tek Kültür ve Sanat } \\
\text { Merkezi }\end{array}$ & 3,30 & 1,51657 \\
\hline $\begin{array}{l}\text { Münire Medresesi El Sanatları } \\
\text { Çarşısı }\end{array}$ & 3,71 & 1,43728 \\
\hline Nasrullah Kadı Külliyesi & 4,10 & 1,20315 \\
\hline Osmanlı Sarayı & 2,42 & 1,39883 \\
\hline Pompeipolis Antik Kenti & 2,39 & 1,35518 \\
\hline Saat Kulesi & 4,41 &, 99690 \\
\hline Sepetçioğlu Konağı & 2,73 & 1,53393 \\
\hline $\begin{array}{l}\text { Taşköprü Kalekapı (Donalar) } \\
\text { Kaya Mezarı }\end{array}$ & 2,40 & 1,47349 \\
\hline Taşköprü Kent Tarihi Müzesi & 2,27 & 1,40763 \\
\hline Yakupağa Külliyesi & 3,94 & 1,27992 \\
\hline Yılanlı Külliyesi & 3,48 & 1,52044 \\
\hline
\end{tabular}

\section{Kastamonu'nun Taşıdığı Değerler ve Sahip Olduğu Değerlere İlişkin Önem Ortalaması}

Kastamonu'nun taşıdığı değerler ve sahip olduğu varlıkların hangileriyle ön plana çıktığına ilişkin katılımcıların görüşleri alınmış ve buna yönelik verilen cevapların önem ortalamaları saptanmıştır. Bu doğrultuda, Tablo 3'de belirtildiği üzere, doğal varlıklar ve güzellikler $(4,45)$ ve tarihi eserler (müze, han vs.) $(4,33)$ en çok ön plana çıkan değerler olarak belirlenirken, festivalleretkinlikler $(2,74)$ en az öne çıkan öğeler olarak ifade edilmiştir. Burada da en düşük standart sapma $(0,95)$ ile doğal varlıklar ve güzellikler seçeneğine verilen cevapların benzeştiği anlaşılmaktadır.

Tablo 3. Kastamonu'nun Taşıdığı Değerler ve Sahip Olduğu Değerlere İlişkin Frekans Analizi

\begin{tabular}{lcc}
\hline & Ortalama & ss \\
\hline Tarihi eserler (müze, han vs.) & 4,34 & 1,03550 \\
\hline Arkeolojik kazılar (antik kent, tapınak) & 3,75 & 1,18095 \\
\hline Yöresel mutfağı ve yemekleri & 3,86 & 1,13988 \\
\hline Dini ve manevi yerler & 3,99 & 1,25030 \\
\hline Festivaller, etkinlikler & 2,74 & 1,39222 \\
\hline Tarihi ve manevi ünlü kişiler & 3,69 & 1,25288 \\
\hline Yöresel el sanatları & 3,73 & 1,29035 \\
\hline Doğal varlıklar ve güzellikler & 4,46 &, 95548 \\
\hline
\end{tabular}




\section{Kentin Özelliğine İlişkin Önem Ortalaması}

Katılımcılara kentin hangi özelliğinin dikkatlerini çektiği sorulmuş ve buna ilişkin önem ortalaması analizi yapılmıştır. Tablo 4'de görüldügüü üzere ankete katılan bireyler Kastamonu'nun doğasını $(4,40)$ ve tarihi değerlerini $(3,91)$ en önemli bulur iken şehrin sanayisini $(2,23)$ en az önemli bulmuşlardır. Özellikle, doğa ifadesinin standart sapmasının 1,13 ile en düşük çıkması katılımcıların bu ifadeye verdiklerin yanıtların birbirine yakın olduğunu göstermektedir.

Tablo 4. Kentin Özelliğine İlişkin Frekans Analizi

\begin{tabular}{lcc}
\hline & Ortalama & ss \\
\hline Kültürel Değerleri & 3,90 & 1,31285 \\
\hline Görünüşü & 3,41 & 1,40765 \\
\hline Tarihi Değerleri & 3,91 & 1,39284 \\
\hline Yemekleri & 3,28 & 1,42748 \\
\hline Şehir Halkı & 2,88 & 1,55059 \\
\hline Mimari Yapısı & 3,43 & 1,48998 \\
\hline Sanayisi & 2,23 & 1,38423 \\
\hline Şehrin kendine has yapısı & 3,49 & 1,44395 \\
\hline Alışveriş Yerleri & 2,50 & 1,53489 \\
\hline Doğası & 4,41 & 1,13226 \\
\hline
\end{tabular}

\section{Kastamonu'nun Tavsiye Edilmesine İlişkin Frekans Analizi}

Katılımclara, 'Bir turizm destinasyonu olarak Kastamonu'yu arkadaşlarınıza ve akrabalarınıza tavsiye eder misiniz?' sorusu yöneltilmiştir ve Tablo 5'te görüldüğü gibi, alınan cevaplara bakıldığında ankete katılan katılımcıların \%69,6'sı Kastamonu'yu çevrelerindeki insanlara da tavsiye edeceklerini belirtirken, \%11,3'lük bir kesim ise tavsiye etmeyeceklerini ifade etmişlerdir.

Tablo 5. Kastamonu'nun Tavsiye Edilmesine İlişkin Frekans Analizi

\begin{tabular}{lll}
\hline & $\mathbf{n}$ & $\mathbf{\%}$ \\
\hline Evet & 160 & 69,6 \\
\hline Hayır & 26 & 11,3 \\
\hline Henüz karar vermedim & 44 & 19,1 \\
\hline Toplam & 230 & 100,0
\end{tabular}

\section{Normallik Testi}

Çalışmada ortaya konan hipotezler için yapılacak olan karşılaştırma testlerinde, ihtiyaç duyulan varsayımlardan biri de verilerin normal dağılıma sahip olmasıdır. Bu nedenle, anket formunda kullanılan ölçeğe normallik testi uygulanmıştır. Elde edilen verilerin normal dağılıp dağılmadığı Tablo 6'da da belirtildiği üzere, Kolmogorov-Smirnov ve Shapiro-Wilk normallik sinamalarına göre incelenmiştir ve verilerin normal dağıldığı belirlenmiştir $(P>0,05)$. Bu nedenle, karşılaştırmalı analizlerde parametrik testler kullanılmıştır. 
Tablo 6. Normallik Testi

\begin{tabular}{|c|c|c|c|c|c|c|}
\hline & \multicolumn{3}{|c|}{ Kolmogorov-Smirnov $^{\mathrm{a}}$} & \multicolumn{3}{c|}{ Shapiro-Wilk } \\
\cline { 2 - 7 } & İstatistik & df & P & İstatistik & df & P \\
\hline $\begin{array}{c}\text { Külttürel Miras } \\
\text { Farkındalığ }\end{array}$ &, 045 & 230 &, $200^{*}$ &, 988 & 230 &, 052 \\
\hline
\end{tabular}

\section{Karşılaştırma Testleri}

Araştırmanın bu kısmında, kültürel miras farkındalığının katılımcıların demografik özelliklerine göre istatistiksel olarak anlamlı farklılıklar gösterip göstermediğini incelemek için bağımsız gruplar $\mathrm{t}$ testi ve tek yönlü ANOVA testi kullanılmıştır. Bağımsız Gruplar T Testi, birbirinden bağımsız iki nicel grubun değişkenler bakımından karşılaştırılması için kullanılan testtir; Tek Yönlü ANOVA ise normal dağılım gösteren $\mathrm{k}(\mathrm{k} \geq 2)$ adet ana kütleden alınan, $\mathrm{k}$ adet bağımsız grup ortalaması arasındaki farklılığın belirlenmesinde kullanılan bir tekniktir (Lorcu, 2015).

\section{Kültürel Miras Farkındalığının Cinsiyet Açısından Karşılaştırılması}

Araştırmanın birinci hipotezi "H1: Kültürel miras farkındalığı cinsiyete göre farklılık göstermektedir.", şeklinde belirlenmiştir. Söz konusu hipotezi sınamak için bağımsız örneklem t-testi yapılmıştır (Tablo 7).

Tablo 7. Kültürel Miras Farkındalığının Cinsiyete Göre T-Testi Sonuçları (n=230)

\begin{tabular}{|l|l|c|c|c|c|c|}
\hline Cinsiyetiniz & & $\mathbf{n}$ & Ortalama & ss & $\mathbf{t}$ & $\mathbf{p}$ \\
\hline Külttürel Miras & Kadın & 142 & 3,37 &, 83056 & 1,070 &, 286 \\
Farkındalığı Ölçeği & Erkek & 88 & 3,24 &, 92332 & & \\
\hline
\end{tabular}

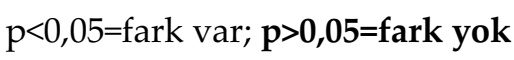

Tablo 7'deki bulgulardan hareketle, kültürel miras farkındalığına ilişkin algıların cinsiyet değişkeni açısından istatistiksel olarak anlamlı bir farklılık göstermediği anlaşılmaktadır ( $p>0,05)$. Bu nedenle, $\mathrm{H} 1$ hipotezi reddedilmiştir.

\section{Kültürel Miras Farkındalığının Yaş Açısından Karşılaştırılması}

Araştırmanın ikinci hipotezi “H2: Kültürel miras farkındalığı yaşa göre farklılık göstermektedir.", şeklinde belirlenmiştir.

Bu hipotezde karşılaştırılacak grup sayısı ikiden fazla olduğu için yine tek yönlü ANOVA testi uygulanmıştır. İlk olarak, varyansların homojenliği test edilmiştir ve varyansların homojen olduğu sonucu ortaya çıkmıştır $(p=0,320, p>0,05)$. Ardından, grupların karşılaştırılması için tek yönlü ANOVA testi uygulanmıştır. ANOVA testi sonuçlarına bakıldığında, Kültürel Miras Farkındalığı Ölçeği bakımından, farklı yaş grupları arasında istatistiksel olarak anlamlı bir farklılık bulunmuştur $(\mathrm{p}<0,05)$. Buradan hareketle, $\mathrm{H} 2$ hipotezinin kabul edildiği ortaya çıkmıştır. Analiz sonuçları Tablo 8' de verilmiştir. 
Tablo 8. Kültürel Miras Farkındalığı Ölçeğinin Yaşa Göre Tek Yönlü ANOVA Sonuçları

\begin{tabular}{|c|c|c|c|c|c|c|}
\hline \multirow{5}{*}{$\begin{array}{l}\text { Kültürel } \\
\text { Miras } \\
\text { Farkındalığ1 } \\
\text { Ölçeği }\end{array}$} & Yaş & $\mathbf{n}$ & Ortalama & ss & F & $\mathbf{P}$ \\
\hline & $18-24$ & 208 & 3,26 & 82510 & \multirow[t]{4}{*}{5,52} & \multirow{4}{*}{0,00} \\
\hline & $25-31$ & 16 & 3,69 & 1,05019 & & \\
\hline & 32 ve üzeri & 6 & 4,24 & 1,16857 & & \\
\hline & Toplam & 230 & 3,32 & 86740 & & \\
\hline
\end{tabular}

$\mathrm{p}<0,05=$ fark var; $\mathbf{p}>\mathbf{0 , 0 5}=$ fark yok

Kültürel miras farkındalığı ölçeğinin yaşa göre farklılığın nereden kaynaklandığını belirlemek için Tukey HSD testi yapılmıştır. Uygulanan bu karşılaştırma testine göre; 18-24 yaş grubu diğer iki yaş grubu ile kıyaslandığında, 32 ve üzeri yaş grubu ile arasında fark olduğu belirlenmiştir $(\mathrm{p}=0,016, \mathrm{p}<0,05)$.

Tablo 9. Kültürel Miras Farkındalığının Hangi Yaş Grupları Arasında Farklılaştığını Belirlemek İçin Yapılan Tukey HSD Testi

\begin{tabular}{|c|c|c|c|c|c|}
\hline & Bölümler (I) & Bölümler (J) & $\begin{array}{l}\text { Ortalama } \\
\text { Farkı }(\mathrm{I}-\mathrm{J})\end{array}$ & ss & $\mathrm{P}$ \\
\hline \multirow{6}{*}{ Tukey HSD } & \multirow{2}{*}{$18-24$} & $25-31$ &,- 43189 & ,22071 & ,125 \\
\hline & & 32 ve üzeri &,$- 97703^{*}$ & ,35229 & , 016 \\
\hline & \multirow[t]{2}{*}{$25-31$} & $18-24$ & ,43189 & ,22071 & ,125 \\
\hline & & 32 ve üzeri &,- 54514 & ,40726 & ,375 \\
\hline & \multirow[t]{2}{*}{32 ve üzeri } & $18-24$ & ,97703* & ,35229 & , 016 \\
\hline & & $25-31$ &, 54514 & ,40726 & ,375 \\
\hline
\end{tabular}

\section{Kültürel Miras Farkındalığının Bölüm Açısından Karşılaştırılması}

Araştırmanın üçüncü hipotezi “H3: Kültürel miras farkındalı̆̆ı bölüme göre farklılık göstermektedir.", şeklinde belirlenmiştir.

Bu hipotezde de karşılaştırılacak grup sayısı ikiden fazla olduğu için yine tek yönlü ANOVA testi uygulanmıştır. İlk olarak, varyansların homojenliği test edilmiştir ve varyansların homojen olduğu sonucu ortaya çıkmıştır ( $\mathrm{p}=0,677, \mathrm{p}>0,05)$. Bu grupların karşılaştırılması için tek yönlü ANOVA testi uygulanmıştır. ANOVA testi sonuçlarına bakıldığında, kültürel miras farkındalığ bakımından, turizm fakültesi bünyesinde farklı bölümlerde gruplar arasında istatistiksel olarak anlamlı bir farklılık bulunmamıştır $(\mathrm{p}>0,05)$. Buradan hareketle, H3 hipotezinin reddedildiği ortaya çıkmıştır. Analiz sonuçları Tablo 10'da verilmiştir.

Tablo 10. Kültürel Miras Farkındalığı Ölçeğinin Bölümlere Göre Tek Yönlü ANOVA Sonuçları

\begin{tabular}{|c|c|c|c|c|c|c|}
\hline \multirow{5}{*}{$\begin{array}{l}\text { Kültürel } \\
\text { Miras } \\
\text { Farkındalığı } \\
\text { Ölçeği }\end{array}$} & Bölüm & n & Ortalama & ss & F & $\mathbf{P}$ \\
\hline & $\begin{array}{l}\text { Turizm } \\
\text { İșletmeciliği }\end{array}$ & 62 & 3,20 & 87909 & \multirow[t]{4}{*}{1,07} & \multirow[t]{4}{*}{0,343} \\
\hline & $\begin{array}{l}\text { Turizm } \\
\text { Rehberliği }\end{array}$ & 123 & 3,40 & ,88587 & & \\
\hline & $\begin{array}{l}\text { Gastronomi ve } \\
\text { Mutfak Sanatlar1 }\end{array}$ & 45 & 3,29 & 79481 & & \\
\hline & Toplam & 230 & 3,32 & ,86740 & & \\
\hline
\end{tabular}

p $<0,05=$ fark var; $p>0,05=$ fark yok 


\section{Katılımcıları En Fazla Etkileyen Yerlere Yönelik Bulgular}

Katılımcılara kapalı uçlu sorulan soruların yanında, açık uçlu sorular da yöneltilmiştir. Katılımcılara bu bölümde yöneltilen ilk soru "Kastamonu ilinde ziyaret ettiğiniz ve sizi en fazla etkileyen yerler neresidir? Önem sırasına göre yazınız. (Lütfen en fazla 3 yer belirtiniz.)" sorusu idi. Katılımcıların cevapları doğrultusunda oluşan kod haritası şu şekildedir:

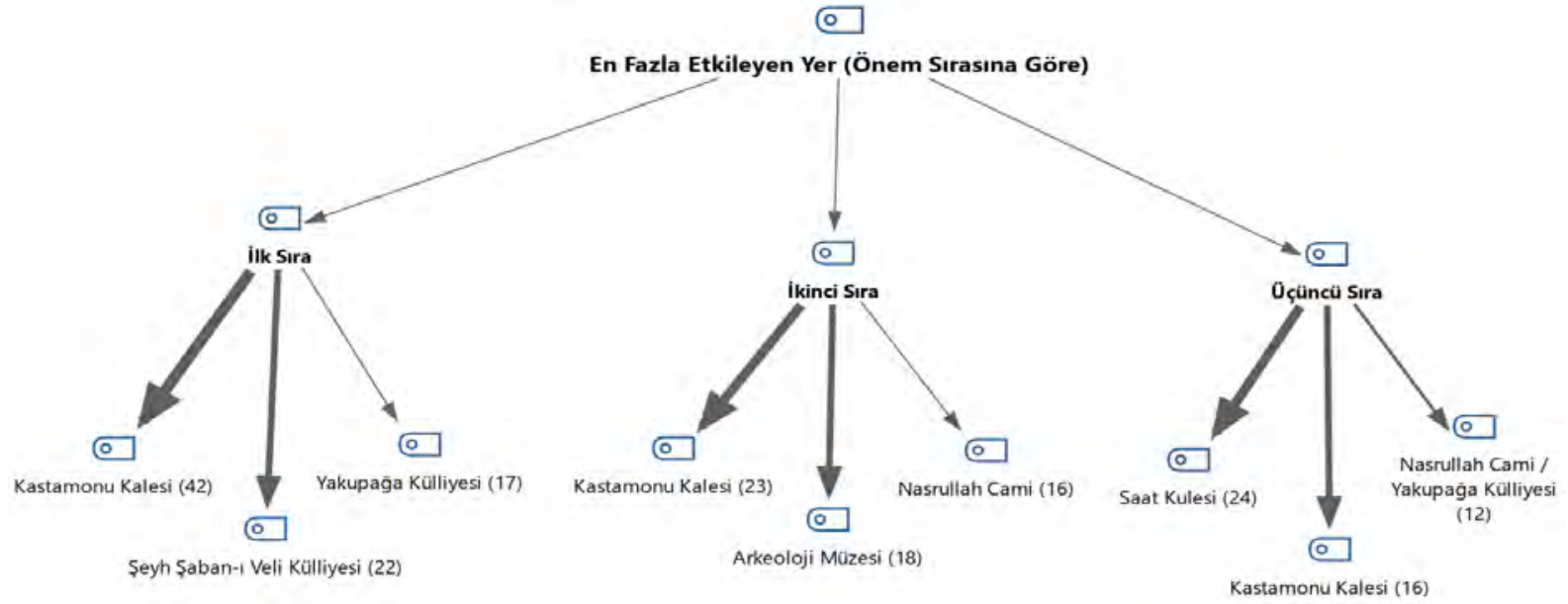

Şekil 1. Katılımcıları En Fazla Etkileyen Yerler

Katılımcıların verdikleri cevaplar incelendiğinde, katılımcıları en çok etkileyen yerlerin başında Kastamonu Kalesi, Şeyh Şaban-1 Veli Külliyesi, Yakupağa Külliyesi, Arkeoloji Müzesi ve Saat Kulesi'nin geldiği Şekil 1'de görülmektedir.

\section{Şehrin Gelişmesi İçin Yapılması Gerekenlere Yönelik Bulgular}

Katılımcılara yöneltilen ikinci açık uçlu soru "Sizce Kastamonu'nun bir turizm destinasyonu olarak gelişmesi için neler yapılmalıdır?" sorusu idi. Katılımcıların cevapları doğrultusunda oluşan kod haritası şu şekildedir:

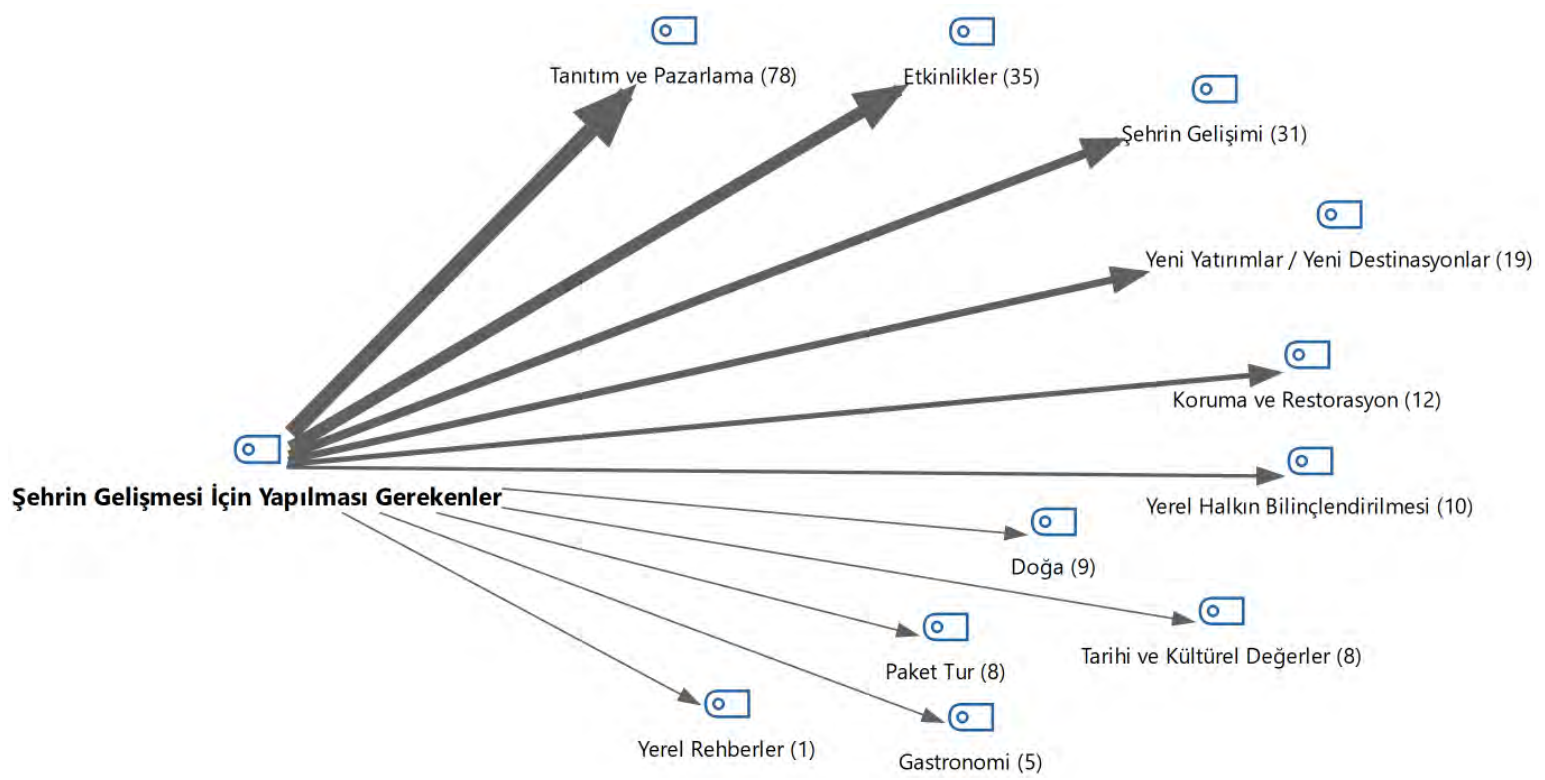

Şekil 2. Şehrin Gelişmesi İçin Yapılması Gerekenler 
Katılımcıların cevapları incelendiğinde Kastamonu turizminin gelişebilmesi için öne çıkan başlıkların "Tanıtım ve Pazarlama, Etkinlikler, Şehrin Gelişimi, Yeni Yatırımlar / Yeni Destinasyonlar, Koruma ve Restorasyon" oldukları Şekil 2'de görülmektedir. Bu sonuçlardan hareketle, iyi bir tanıtım ve pazarlama stratejisi hazırlanmasının, çeşitli etkinliklerin / festivallerin düzenlenmesinin, şehrin alt yapı ve üst yapı çalışmalarının daha fazla yapılmasının şehrin turizminin gelişimine önemli katkıda bulunacağı varsayılmaktadır. Katılımcıların cevapları doğrultusunda öne çıkan alıntılar ise şu şekildedir:

Tablo 11. Şehrin Gelişmesi İçin Yapılması Gerekenlere Yönelik Öne Çıkan Doğrudan Alıntılar

\begin{tabular}{|c|c|c|}
\hline Katılımcı & Kod & Alintı \\
\hline K38 & $\begin{array}{c}\text { Tanıtım ve } \\
\text { Pazarlama / Doğa }\end{array}$ & $\begin{array}{l}\text { "Kastamonu'yu biraz daha yol üstü bir yere çekmek mümkün } \\
\text { olmadığı için tek yapılabilecek şey daha fazla tanıtım. Ayrıca doğası } \\
\text { çok güzel aslında, Artvin'de sırf doğa turları yapıldığını duydum. } \\
\text { Bence Kastamonu için de bunlar düzenlenebilir, zaten varsa da } \\
\text { sayıları arttırılıp daha fazla reklamı yapılabilir." }\end{array}$ \\
\hline K55 & $\begin{array}{c}\text { Koruma ve } \\
\text { Restorasyon / } \\
\text { Doğa }\end{array}$ & $\begin{array}{l}\text { "Kesinlikle konakları ve kültürel yerleri çok fazla ve bir harika ama } \\
\text { bakımsız ve gerekli özem gösterilmiyor. Doğası muhteşem ve çok } \\
\text { iyi değerlendirilebilir ama yeteri kadar üstüne düşülmüyor. Ĕger } \\
\text { bakım ve reklamı yapılsa Türkiye'deki en iyi kültürel ve doğal } \\
\text { destinasyonlar arasına girebilir." }\end{array}$ \\
\hline K69 & Şehrin Gelişimi & $\begin{array}{l}\text { "Ilgaz Dağı'nın reklamının yapılması gerek. Ayrıca şekil içindeki } \\
\text { doğal görüntüyü bozan binaların en azından ahşap görünümlü } \\
\text { hale getirilmesi gerek. Herkes Safranbolu'nun evlerinin çok } \\
\text { olduğunu düşünmekte bu yargının kalkması gerek. Özellikle daha } \\
\text { gelişmiş bir ulaşım altyapısı olması gerek. Şahsen ben İstanbul'dan } \\
\text { gelirken havabus dediğimiz büyük otobüslere biniyoruz. } \\
\text { Havalimanı da bu şekilde ayarlanmalı. Özellikle doğa bakımından } \\
\text { çok zengin bir şehir, bungalov evleri ama özelikle ahşaptan olması } \\
\text { gerek. Özellikle orman bölümlerine parkur yapılabilir. İstanbul'da } \\
\text { bazı ormanlarda mangal yapılmıyor mangala benzer ocaklar var o } \\
\text { tür düzenekler kurulabilir. Özellikle oteller arttırılmalı ve daha } \\
\text { özenilmelidir." }\end{array}$ \\
\hline K84 & $\begin{array}{c}\text { Yeni Yatırımlar / } \\
\text { Yeni } \\
\text { Destinasyonlar }\end{array}$ & $\begin{array}{l}\text { "Sanayisi, ulaşımı, mağazaları ve yöresel yemeklerin daha ön } \\
\text { planda olabilmesi için büyük yatırımlar şart. Eski ve yıkık dökük } \\
\text { şehir olursanız ne kadar da tarihi yerleriniz, dini yerleriniz olursa } \\
\text { olsun, gelen turist ulaşımın, yemek yendiği ve alışveriş yaptığ } \\
\text { yerlerin olmasını ister. Şuan } 1 \text { kez gelip } 2 . y i \text { ne gerek var bir daha } \\
\text { gelmeye dedirtiyoruz. Oysaki bir turisti her sene getirmeye } \\
\text { çalı̧sak, bir daha ki sene daha fazla turist gelmiş olur." }\end{array}$ \\
\hline K150 & $\begin{array}{c}\text { Tarihi ve Kültürel } \\
\text { Değerler / } \\
\text { Gastronomi / } \\
\text { Doğa }\end{array}$ & $\begin{array}{l}\text { "Daha çok kültür, yemek ve doğa üzerinden gidilmeli benim } \\
\text { düşünceme göre. Yapılmaya çalışllan dini değerlerin öne } \\
\text { çlkartılmaya çalışılması ise hiçbir işe yaramadığı görüşündeyim. } \\
\text { Şehir merkezinde, binlerce arabanın geçtiği ve etrafı göze hitap } \\
\text { etmeyen apartmanlarla dolu dini destinasyonlar yerine, doğanın } \\
\text { göbeğinde Ilgaz gibi milli parkların tanıtılması çok daha önemlidir. } \\
\text { Bununla birlikte Yunanistan gibi ülkelerde fazlasıyla ilgi çeken } \\
\text { antik kentlerin bir tanesine de sahip olan şehrimizin, en azından } \\
\text { yurt dışından gelen turistler adına bunu geliştirmesi gerektiŏi } \\
\text { kanısındayım." }\end{array}$ \\
\hline
\end{tabular}




\begin{tabular}{|c|c|c|}
\hline K166 & $\begin{array}{c}\text { Tanitım ve } \\
\text { Pazarlama / } \\
\text { Koruma ve } \\
\text { Restorasyon / } \\
\text { Şehrin Gelişimi }\end{array}$ & $\begin{array}{l}\text { "Kesinlikle devlet kuruluşlarından destek alınarak tanıtımı } \\
\text { yapılmalı çünkü Kastamonu denilince insanlar genel olarak Ilgaz, } \\
\text { sarımsak ve doğası dışında hiçbir şey bilmiyor. Bu da şehrin } \\
\text { reklamının iyi yapılmadığının büyük bir göstergesi. Ve her şey bir } \\
\text { yana şehrin içinde bulunan turist çekebilecek yerler hiçbir şekilde } \\
\text { tadilat yapılmamış resmen dökülmeye muhtaçbırakılmışbir şekilde } \\
\text { terk edilmiş gibi. (Buna en çok dahil olan yerler konaklar.) Bir de } \\
\text { bu turistlik yerlerin ziyaretinde insanların en çok zorlandığı şey } \\
\text { ulaşım ve araçlarını park edecek bir yer bulamamaları. Şehirde } \\
\text { yürüyerek gezmek isteyenler için ise yol gösterici tabela vb. şeyler } \\
\text { mevcut değil. Tüm bunlara ise insanların pek yapabileceği bir şey } \\
\text { olmadığından bilir kişiler tarafından düzeltilmesinden başka } \\
\text { geliştirici bir etken var mı bilemiyorum." }\end{array}$ \\
\hline
\end{tabular}

\section{TARTIŞMA}

Herhangi bir topluma ait kültürel mirasın korunması aynı zamanda insanlık tarihinin de bir şekilde korunması anlamına gelmektedir. Bu nedenle kültürel miras farkındalığı konusu özellikle geleceğin mirasçıları olan genç bireyler için önem arz etmektedir. Kültürel miras farkındalığı ile ilgili alan yazın incelendiğinde çeşitli eğitim düzeylerinde eğitim alan öğrencilere yönelik olarak çalışmaların yapıldığı görülmektedir. Üniversite öğrencilerine yönelik yapılan kültürel farkındalık çalışmaları sonuçları genel olarak öğrencilerin kültürel miras farkındalık düzeylerinin yeterli düzeyde olmadığı yönündedir. Bahtiyar Karadeniz (2020) ve Bahtiyar Karadeniz vd., (2018) üniversite öğrencilerinin kültürel miras farkındalık düzeylerinin orta düzeyde olduğu sonucuna ulaşmışken, Dinç vd. (2011), Metin (2012), Aktın vd. (2013), Akkuş vd. (2015), Keçe (2015), Karaca-Yılmaz vd. (2017) ve Buluk (2017) üniversite öğrencilerinin kültürel miras farkındalık düzeylerinin düşük olduğu sonucunu elde etmişlerdir. Ancak bu çalışmada üniversite öğrencilerinin Kastamonu tarihi ve kültürel değerlere ilişkin farkındalık düzeylerinin yüksek olduğu sonucuna varılmıştır. Bu sonuç Dikmenli ve Çetin (2014)'in çalışması ile paralellik göstermektedir.

$\mathrm{Bu}$ çalışmada öğrencilerin kültürel miras farkındalığı bakımından cinsiyet ve eğitim alınan bölümler açısından anlamlı bir farklılık bulunmazken, Dinç vd., (2011) ve Aktın vd., (2013)'nin çalışmasında öğrencilerin farkındalık seviyeleri öğrenim görülen bölüme göre farklılaşmakta ve erkek öğrencilerin kız öğrencilere göre farkındalık düzeylerinin daha yüksek olduğu görülmüştür. Çetin ve Gürgil (2014), Akkuş vd., (2015) ve Mancı (2019)'nın çalışmalarında da öğrenim görülen bölüme göre farklılık elde edilen sonuçlar arasındadır. Güneş ve Alagöz (2018) turizm eğitimi alan öğrenciler üzerine yaptıkları çalışma sonucunda öğrenim görülen bölüme göre kültürel miras farkındalıkları bakımından anlamlı farklılık görülmüştür. Bunun yanı sıra bu çalışma sonucunda elde edilen kültürel miras farkındalığının bölümlere göre farklılık göstermediği bulgusu ile Güdü-Demirbulat vd., (2015)'nin çalışma sonucu ile, cinsiyet açısından anlamlı bir farklılık bulunmaması bulgusu ile Güneş ve Alagöz (2018)'ün çalışma sonucu ile aynı doğrultudadır. Ancak birçok çalışmada öğrencilerin öğrenim gördükleri bölümün kültürel miras farkındalık düzeylerinde farklılık gösterdiği ortak bulgudur (Dinç vd., 2011). Bu farkındalık düzeylerinde görülen farklılığın eğitim alınan bölümlerin müfredatlarında yer alan dersler ile ilgili olduğu söylenebilir.

$\mathrm{Bu}$ çalışma sonucuna göre, genel olarak öğrencilerin şehir merkezinde yer alan tarihi yapılara yönelik farkındalık düzeylerinin, şehir merkezi dışında (ilçelerde) bulunanlara göre daha yüksek 
olduğunu söylemek mümkündür. Karaca-Yılmaz vd., (2017)'nin çalışmasında öğrencilerin tarihi yapılara ilişkin farkındalıklarının orta düzeyde olduğu sonucuna ulaşılmıştır. Karaca-Yılmaz vd., (2017)'nin çalışmasında öğrencilerin farkındalık puanlarının en düşük olduğu alanlar arasında etkinlinler yer almaktadır. Bu sonuçlar çalışmamızın sonuçları ile paralellik göstermektedir.

\section{SONUÇve ÖNERILER}

Kültürel miras, turizm faaliyetinin en önemli unsurlarından biridir. Bir yöreye özgü yöresel yemekler, efsaneler, dini ritüeller, doğal parklar, surlar, şarkılar, el sanatları gibi birçok öğe kültürel miras sayılmaktadır. Kastamonu'nun sahip olduğu turistik ürünler açısından düşünüldügünde ise, kültürel mirasın Kastamonu turizminin geleceği için hayati bir öneme sahip olduğu aşikârdır. Çünkü, Kastamonu çeşitli arkeolojik kalıntılardan, yöresel yemeklere, kanyonlardan, yaylalarına kadar birçok farklı güzelliği içerisinde barındıran bir destinasyondur. Bu noktada, turizmdeki nitelikli çalışan ihtiyacını karşılamak eğitim veren Kastamonu Üniversitesi Turizm Fakültesi öğrencilerinin Kastamonu ile ilgili kültürel miras farkındalıkları merak konusu olmuştur ve araştırmacılar tarafından bu durum tespit edilmeye çalışılmıştır.

Araştırmadan elde edilen bulgular incelendiğinde, katılımcıların kültürel miras farkındalıklarının genel anlamda ortalamanın üzerinde olduğu belirlenmiştir. Özellikle, "Atatürk ve Şerife Bacı Anıtı", "Kastamonu Kalesi" ve "Saat Kulesi"nin en fazla bilinen yerler arasında yer aldığı saptanmıştır. Katılımcılar, Kastamonu'nun daha çok "Tarihi Eserler (müze, han vs.)" ve "Doğal Varlıklar ve Güzellikler" ile ön plana çıktığını ifade etmişlerdir. Katılımcıların büyük çoğunluğu turistik bir destinasyon olarak Kastamonu'yu çevrelerindeki insanlara da tavsiye edeceklerini vurgulamışlardır. Yapılan karşılaştırma testlerinde, kültürel miras farkındalığının katılımcıların cinsiyetlerine ve bölümlerine göre bir farklılık göstermediği, ancak yaş grupları arasında anlamlı farklılıkların bulunduğu tespit edilmiştir. Ayrıca, katılımcıları en çok etkileyen yerler arasında Kastamonu Kalesi, Şeyh Şaban-1 Veli Külliyesi, Yakupağa Külliyesi, Arkeoloji Müzesi, Saat Kulesi ve Nasrullah Camii'nin yer aldığ1 belirlenmiştir. Katılımcılar, Kastamonu turizminin gelişimi için tanıtım faaliyetlerinin etkili bir şekilde yapılması gerektiğini, festival tarzı çeşitli etkinliklerin arttırılmasının son derece önemli olduğunu, alt yapı ve üst yapı çalışmalarının hızlandırılması gerektiğini ve yeni yatırımların yapılmasının elzem olduğunu ifade etmişlerdir.

Bu araştırma ile birlikte, turizm eğitimi alan öğrencilerin Kastamonu'nun sahip olduğu kültürel miras farkındalığı ölçülmeye çalışılmış ve öğrencilerin gözünden Kastamonu turizminin gelişmesi için neler yapılması gerektiği ortaya konmaya çalışılmıştır. Bu araştırmanın ilgili literatüre yapacağı teorik katkının yanında, uygulamada da bazı yararlar sağlayacağ düşünülmektedir. Teorik açıdan ele alındığında, bu araştırmada turizm konusunda her geçen yıl daha iyi bir seviyeye doğru ilerleyen Kastamonu'nun kültürel mirasının ele alınmasının ve bu çıktıların bilimsel ortamda paylaşılmasının literatüre katkıda bulunacağı düşünülmektedir. Uygulamada ise, öğrencilerin hangi noktalarda farkındalık düzeylerinin düşük olduğu belirlenmiş, ayrıca Kastamonu turizminin gelişmesi adına katılımcıların belirttikleri ifadeler incelenmiştir. Böylece, bu çıktılardan hareketle öğrencilerin sundukları önerilerin Kastamonu turizminde söz sahibi olanlar tarafından dikkate alınacağı ve bunun da turizmin gelişimine katkıda bulunacağı düşünülmektedir.

Çeşitli içsel ve dışsal unsurlardan dolayı bu araştırmanın konu edinmediği Kastamonu'nun sahip olduğu kültürel mirasın turizme elverişli olup olmadığı incelenebilir. Ayrıca, Kastamonu'da yaşayan turizm akademisyenlerinin de kültürel miras farkındalığının ölçülmesi gelecek 
araştırmacılar için bir araştırma konusu olabilir. Katılımcıların kültürel miras farkındalığı noktasında en az bildikleri yerler arasında yer alan Taşköprü Kent Tarihi Müzesi'ne $(2,27)$, Pompeipolis Antik Kenti'ne (2,38) ve Taşköprü Kalekapı (Donalar) Kaya Mezarı'na $(2,40)$ yönelik geziler düzenlenmeli. Nitekim, özellikle Pompeipolis Antik Kenti, Kastamonu'nun sahip olduğu en önemli turistik destinasyonların başında gelmektedir. Katılımcılar "Festivaller, etkinlikler" noktasında da Kastamonu'yu yetersiz görmüşlerdir. Bu noktada, Uluslararası Taşköprü Kültür ve Sarımsak Festivali, Kastamonu Ahşap Fuarı ve Cide Rıfat Ilgaz Sarı Yazma Kültür ve Sanat Festivali gibi turizme doğrudan ve dolaylı olarak katkıda bulunabilecek etkinliklerin sayısı ve niteliği artırılmalıdır. Şehir halkının turizme bakış açısının daha olumlu bir hale gelebilmesi için kamu ve özel sektör temsilcileri tarafından turizmin önemi gerek sosyal medya üzerinden gerek yüz yüze konferans biçiminde düzenlenecek organizasyonlarla yerel halka anlatılmalıdır. Kastamonu'nun bir turizm destinasyonu olarak tavsiye edilmesine yönelik ortaya çıkan sonuçlarda, katılımcıların \%11,3'ü "Hayır" cevabını verirken, \%19,1'lik bir kesim "Henüz karar vermedim" yanıtını vermişlerdir. \%30,4'lük bu kesimin neden olumsuz bir tavır takındıkları veya kararsız kaldıkları bir başka araştırmada ele alınabilir. Şehrin turizm alanında gelişmesi noktasında katılımcılar tarafından da ifade edilen, 'tanıtım ve pazarlama', 'yeni yatırımlar / yeni destinasyonlar", "koruma ve restorasyon" gibi alanlarda somut ve nitelikli adımlar atılmalıdır. Bunun yanında, şehrin turizminin gelişimine yönelik araştırma çıktıları Kastamonu Belediyesi, Kastamonu Üniversitesi Turizm Fakültesi, Kastamonu İl Kültür ve Turizm Müdürlügü̈, KUZKA, Kastamonu Otelciler Birliği ve diğer ilgili kamu kuruluşları, özel sektör temsilcileri ve STK'lar tarafından dikkate alınmalı ve gerçekle örtüşen eksikliklerin giderilmesi için çalışmalar yapılmalıdır.

\section{KAYNAKÇA}

Ablak, S., Dikmenli, Y. ve Çetin, T. (2014). Üniversite Öğrencilerinin Kırşehir'in Tarihi ve Kültürel Turizm Değerlerine Yönelik Farkındalıkları. Uşak Üniversitesi Sosyal Bilimler Dergisi, 7(2):171-186.

Akkuş, G., Karaca, Ş. ve Polat, G. (2015). Miras Farkındalığı ve Deneyimi: Üniversite Öğrencilerine Yönelik Keşifsel Bir Çalışma. Akademik Bakış Dergisi, 50: 71-81.

Ahmed, T. S. A. (2017). Assessment of Students' Awareness of the National Heritage: The Preparatory Year Students at the University of Hail, Saudi Arabia. Cogent Social Sciences, 3: 1306202, 2-26.

Akpirinç, E. ve Mancı, A. R. (2019). Yerel Halkın Kültürel Miras Farkındalığ 1 ve Deneyimi: Şanlıurfa Örneği. Uluslararası Güncel Turizm Araştırmaları Dergisi, 3(2): 245-260.

Aktın, K., Karakuş, H. ve Sağlam, H. (2013). Sinop Üniversitesi Öğretmen Adaylarının Sinop İline Ait Tarihi ve Kültürel Eserler Hakkındaki İlgi ve Farkındalık Düzeyleri. The Journal of Academic Social Science Studies, 6(7): 37-59.

Aşık, G., Özel, S. ve Korzay, M. (2016). İlkokul Öğrencilerinin İstanbul'un Kültürel Mirası Farkındalıklarını Arttırmaya Yönelik Bir Eğitim Programı. Uluslararası Gelecek İçin Öğrenme Alanında Yenilikler Konferansı, 24-26 Ekim, İstanbul.

Avcıkurt, C. (2017). Turizm Sosyolojisi Genel ve Yapısal Yaklaşım. (Güncellenmiş 5.Baskı). Ankara: Detay Yayıncilık.

Barghi, R., Zakaria, Z., Jaafar, M. and Hamzah, A. (2017). Students' Awareness and Attitudes toward Archaeological Conservation: Bujang Valley. Journal of Cultural Heritage Management and Sustainable Development, 7(1):48-56. 
Bahtiyar Karadeniz, C., Sarı, S. ve Kabacık, M. (2019). Üniversite Öğrencilerinin Ordu İlinin Doğal ve Kültürel Turistik Çekiciliklerine İlişkin Farkındalık ve Deneyimleri. Karadeniz Sosyal Bilimler Dergisi, 10(19): 667-684.

Bahtiyar Karadeniz, C. (2020). Assessment for Awareness and Perception of the Cultural Heritage of Geography Students. Review of International Geographical Education (RIGEO), 10(1):40-64.

Birleşmiş Milletler Eğitim, Bilim ve Kültür Örgütü (UNESCO) (1972). Dünya Kültürel ve Doğal Mirasın Korunması Sözleşmesi. http://teftis.kulturturizm. gov.tr/TR, 14269/dunya-kulturel-vedogal-mirasinkorunmasi-sozlesmesi.html ve https://whc.unesco.org/en/conventiontext/>[Erişim Tarihi:13.10.2020].

Birleşmiş Milletler Eğitim, Bilim ve Kültür Örgütü (UNESCO) (2003). Somut Olmayan Kültürel Mirasın Korunması Sözleşmesi. https://ich.unesco.org/ doc/src/00009-TR-PDF.pdf $>$ [Erişim Tarihi: 13.10.2020].

Buluk, B. (2017). Turizm Lisans Öğrencilerinin Kültürel Miras Farkındalıkları: Çanakkale Onsekiz Mart Üniversitesi Örneği. Uluslararası Turizm ve Kültürel Miras Kongresi,05-08 Ekim 2017, Muğla.ss.148-155.

Charter of Venice (1964). International Charter for the Conservation and Restoration of Monuments and Sites, https://www.icomos.org/charters/venice_e.pdf > [Erişim Tarihi: 15.10.2020].

Council of Europe. (2005). Council of Europe Framework Convention on the Value of Cultural Heritage for Society, Faro 27.10.2005. https://rm.coe.int/1680083746 > [Erişim Tarihi: 14.10.2020].

Çetin, T. ve Gürgil, F. (2014). Üniversite Öğrencilerinin Bartın'ın Doğal ve Kültürel Turizm Değerlerine Yönelik Farkındalıkları. Uşak Üniversitesi Sosyal Bilimler Dergisi, 7(4): 255- 274.

Doğaner, S. (2003). Miras Turizminin Coğrafi Kaynakları ve Korunması İzmir. Coğrafi Çeore Koruma Turizm Sempozyumu,16-18 Nisan 2003, İzmir. ss.1-8.

Dinç, E. Erdil, M. ve Keçe, M. (2011) Uşak Üniversitesi Öğrencilerinin Tarihi ve Kültürel Eserler Hakkındaki İlgi ve Farkındalıklarının İncelenmesi. Uşak Üniversitesi Sosyal Bilimler Dergisi, 4(2): 267-285.

Emekli, G. (2012). Kültür Mirasının Turizm Aracılığg ile Değerlendirilmesi: Kültürel Turizm ve İzmir. Buca İlçesinin Ekoturizm ve Kültür Turizmi Sektör Analizi Projesi, Kültür Turizmi Çalıştayı,8 Şubat 2012, İzmir Kalkınma Ajansı-Buca Belediyesi, Buca.

Endresen, K. (1999). Sustainable Tourism and Cultural Heritage. A Review of Development Assistance and It's Potential to Promote Sustainability. New World Hope Organization.

Güdü Demirbulat, Ö., Saatçi, G. ve Avcıkurt, C. (2015). Bursa'nın Somut Kültürel Varlıklarına Yönelik Öğrencilerin Algıları: Harmancık MYO Örneği. Gümüşhane Üniversitesi Sosyal Bilimler Elektronik Dergisi, (12): 62-86.

Gümüş, N. ve Özüpekçe, S. (2009). İlköğretim Okulu Öğrencilerinin Turizme Yönelik Görüşleri: Foça Örneği. Dokuz Eylül Üniversitesi Buca Eğitim Fakültesi Dergisi, 25: 25-34.

Gümüş, N. ve Adanalı, R. (2011). Buca'da (İzmir) Tarihi ve Kültürel Mirasa Yönelik Ortaöğretim Öğrencilerinin Tutum ve Davranışları. Dokuz Eylül Üniversitesi Buca Eğitim Fakültesi Dergisi, (30): 87-102.

Güneş, E. ve Alagöz, G. (2018). Turizm Eğitimi Alan Öğrencilerin Kültürel Miras Tutumları Üzerine Bir Araştırma. Adıyaman Üniversitesi Sosyal Bilimler Enstitüsü Dergisi, (29): 753-777. 
Gürel, D. and Çetin, T. (2017). An Investigation of Secondary School 7th Grade Students' Awareness for Intangible Cultural Heritage. Journal of Education and Practice, 8(27): 75-84.

https://dictionary.cambridge.org/dictionary/english/culture>[Erişim tarihi: 01.10.2020].

https://www.oxfordlearnersdictionaries.com/definition/english/culture_1?q= culture $>$ [Erişim tarihi: 01.10.2020].

Jaafar, M., Noor, S. M. and Rasoolimanesh, S. M. (2014). Awareness and Willingness for Engagement of Youth on World Heritage Site: A Study on Lenggong Archaeological Site. Asian Social Science, 10(22): 29-36.

Jokilehto, J. (2005). Definition of Cultural Heritage. Rome: ICCROM Working Group “Heritage and Society".

İstanbul Valiliği (2014). Kültürel Mirasın Korunması, İSMEP Rehber kitaplar. [Online] http://www.guvenliyasam.org/wp-content/uploads/2016/02/KULTUREL.pdf $>$ [Erişim Tarihi: 14.10.2020].

Karaca Yılmaz, Ş. ve Şahbudak, E., Akkuş, G. ve Işkın, M. (2017). Kültürel Miras Farkındalığı: Cumhuriyet Üniversitesi Öğrencilerine Yönelik Bir Uygulama Çalışması. Akademik Araştırmalar ve Çalışmalar Dergisi, 9(16), 80-101.

Karasar, N. (1984). Bilimsel Araştırma Metodu. Ankara: Hacettepe Taş Kitapçllık.

Kastamonu İl Kültür ve Turizm Müdürlüğü (2020). Turizm Değerleri. [Online] https://kastamonu.ktb.gov.tr/TR-63872/turizm-degerleri.html > [Erişim tarihi: 21.03.2021].

Keçe, M. ve Dinç, E. (2010) Öğretmen Adaylarının Tarihî ve Kültürel Eserler Hakkındaki İlgi ve Farkındalıklarının İncelenmesi. I. Uluslararası Tarih Eğitimi Sempozyumu, 16-18 Haziran 2010, Erzurum.

Keçe, M. (2015) Sosyal Bilgiler Öğretmen Adaylarının Ankara'nın Tarihi ve Kültürel Turizm Değerlerine Yönelik İlgi ve Farkındalıkları. Ahi Evran Üniversitesi Kırşehir Eğitim Fakültesi Dergisi (KEFAD), 16(1): 131-149.

Köroğlu, Ö., Ulusoy Yıldırım, H. ve Avcıkurt, C. (2018). Kültürel Miras Kavramına İlişkin Algiların Metafor Analizi Yoluyla İncelenmesi. Turizm Akademik Dergisi, 5(1): 98-113.

Krejcie, R. V. and Morgan, D. W. (1970). Determining Sample Size for Research Activities. Educational and Psychological Measurement, 30(3): 607-610.

Kültür ve Turizm Bakanlığı. (2009). Kültürel Miras ve Müzecilik. http://teftis. kulturturizm.gov.tr/ Eklenti/1279, muserrefcanpdf.pdf?0 >[Erişim tarihi: 13.10.2020].

Lorcu, F. (2015). Örneklerle Veri Analizi SPSS Uygulamall. Ankara: Detay Yayıncılık.

Manc1, A. R. (2019). Üniversite Öğrencilerinin Kültürel Miras Farkındalığı ve Deneyimleri: Harran Üniversitesi Örneği-Şanlıurfa. Türk Turizm Araştırmaları Dergisi, 3(4): 1164-1177.

Metin, E. (2010). Tarih Bölümü Öğrencilerinin Tarihi ve Kültürel Eserler Hakkındaki İlgi ve Farkındalıklarının İncelenmesi. Millî Mücadelede "İstiklal Yolu" ve Çankırı Sempozyumu, 21-23 Ekim 2010, Çankırı.

Meydan Uygur, S. ve Baykan, E. (2007). Kültür Turizmi ve Turizmin Kültür Turizmi ve Turizmin Kültürel Kültürel Varlıklar Üzerindeki Etkileri. Journal of Commerce, (2): 30-49.

Selanik Ay, T. ve Kurtdede Fidan, N. (2013). Öğretmen Adaylarının“Kültürel Miras” Kavramına İlişkin Metaforları. Electronic Turkish Studies, 8(12): 1135-1152. 
Shankar, B. and Swamy, C. (2013). Creating Awareness for Heritage Conservation in The City of Mysore: Issues and Policies. International Journal of Modern Engineering Research (IJMER), 3(2): 698703.

Shimray, S. R. and Ramaiah, C. K. (2017). Issues in Preservation of Digital Cultural Heritage. ReEnvisioning Role of Libraries: Transforming Scholarly Communication (pp. 146-157). Gandhinagar: INFLIBNET Centre.

Shimray, S.R. and Ramaiah, C.K. (2019). Cultural Heritage Awareness among students of Pondicherry University: aStudy. Library Philosophy and Practice. 1-10.

Skounti, A. (2011). The Lost Ring: UNESCO's World Heritage and Intangible Cultural Heritage. Milli Folklor, 23(89): 28-40.

Srivastava, S. (2015). A Study of Awareness of Cultural Heritage among the Teachers at University Level. Universal Journal of Educational Research, 3(5), 336-344.

Şekerci, H. ve Doğan, M. C. (2020). İlkokul Sosyal Bilgiler Öğretimi Bağlamında Öğrencilerin Tarihi Mekânlara İlişskin Algılarının Metaforlar Yardımıyla İncelenmesi. Erzincan Üniversitesi Eğitim Fakültesi Dergisi, 22(2): 464-480.

Tören, E., Kozak, N. ve Demiral, G. N. (2012). Eskişehir'in Kültürel Miras Varlıklarının Korunmasında Kamu Kurumlarının Rolü. Aksaray Üniversitesi İ̈BF Dergisi, 4(2): 69-88.

Türk Dil Kurumu, Kültür tanımı, https://sozluk.gov.tr/>[Erişim tarihi: 01.10.2020].

Uçar, M. (2014). İlköğretim Düzeyinde Kültür Varlığı ve koruma Konularındaki Eğitiminin Etkinliği ve Sivil Toplum Örgütlerinin Eğitime Katkısının Değerlendirilmesi. Megaron, 9(2): 8597.

Uluslararası Kültürel Turizm Tüzügü (ICOMOS) (1999). Kültürel Miras Değeri Taşıyan Alanlarda Turizm Yönetimi, http://www.icomos.org.tr/Dosyalar/ICOMOSTR_tr0300983001536913522.pdf $>$ [Erişim tarihi: 10.11.2020].

Vecco, M. (2010). A Definition of Cultural Heritage: From the Tangible to the Intangible. Journal of Cultural Heritage, 11(3): 321-324.

Yaşarsoy, E.ve Oktay, K. (2020). Yerli Turistlerin Şanlıurfa Turizmi ile İlgili Algılarını Belirlemeye Yönelik Bir Araştırma. Journal of Tourism and Gastronomy Studies, 8(1): 58-77.

Yıldırım, A. ve Şimşek H. (2008). Sosyal Bilimlerde Nitel Araştırma Yöntemleri. Ankara: Seçkin Yayıncilik. 